\title{
Diel dynamics of heleoplankton in relation to some physico-chemical attributes of water in an aquaculture tank in Guwahati, Assam
}

\author{
J anardan Pathak ${ }^{1}$ and M . M . Goswami ${ }^{*}$ \\ ${ }^{1}$ G.U. Model H.E. School, G.U. Campus, Jalukbari, Guwahati-781 014, INDIA \\ ${ }^{2}$ Department of Zoology, Gauhati University, Jalukbari, Guwahati-781 014, INDIA \\ *Corresponding author. E-mail: mrigen_goswami@ rediffmail.com
}

\begin{abstract}
Diurnal fluctuation of the phytoplankton and zooplankton population (numerical densities) and the physicochemical attributes of water are studied in an aquaculture pond at Guwahati, Assam. In the 24 hour diel cycle, the phytoplankton and zooplankton show significant (t-test, $p<0.01$ ) variation in their numerical density at an interval of 4 hours. The studied physico-chemical parameters of water included Temperature, Total Alkalinity (TA), Total hardness $(\mathrm{TH})$, Dissolved Oxygen (DO), Free Carbon dioxide $\left(\mathrm{FCO}_{2}\right)$ and $\mathrm{pH}$ are analyzed concurrently, which reveals a significant fluctuation (t-test, $\mathrm{p}<.01$ ) in the day and night hours. Multivariate correlation analysis portrays significant and positive correlations among the total population density of phytoplankton with respect to water temperature $(r=$ $0.845, \mathrm{p}<0.05)$ and $\mathrm{pH}(\mathrm{r}=0.881, \mathrm{p}<0.01)$ while it maintains significant negative correlations with $\mathrm{TA}(\mathrm{r}=-0.837, \mathrm{p}<$ $0.05), \mathrm{TH}(r=-0.768, p<0.05)$ and $\mathrm{FCO}_{2}(r=-0.830, p<0.05)$. However, total numerical density of zooplankton reveals positive and significant correlations with TA $(r=0.842, p<0.05)$ and $\mathrm{FCO}_{2}(r=0.758, p<0.05)$ while it shows significant negative correlations with water temperature $(r=-0.906, p<0.01)$ and $\mathrm{pH}(r=-0.912, p<0.01)$.
\end{abstract}

Keywords: Aquaculture pond, Diurnal variation, Heleoplankton, Physico-chemical parameters

\section{INTRODUCTION}

Diurnal variation in plankton is apparent in tropical as well as temperate water bodies. The phytoplankters are found abundantly in the surface water during the day hours while zooplanktons are copiously found in the night hours. It has been found that diel fluctuation of plankton is guided by a number of physico-chemical parameters and biological components of an aquatic system (Lampert, 1993; Melo and Huszar, 2000, Pinilla, 2006). The light has been considered as the most important factor triggering the diel vertical migration of plankton (Ringelberg and Van Gool, 2003). However, other environmental factors such as temperature (Haney, 1993), dissolved oxygen (Hanazato and Yasuno, 1989; Horpilla et al., 2000) and availability of food (Leibold, 1990) are also involved in regulating such behaviours of plankton. Many zooplankters exhibit diel vertical migration as a defense to avoid predation by larger insects and fishes (Muluk and Baklioglu, 2005; Pasternak et al., 2006). In the presence of fish, they migrate to the deeper water during the day hours, where there is insufficient light and low dissolved oxygen, both of which are unfavourable for the fishes. On the other hand, they (zooplankton) migrate upward and stay near the surface at night, when there is abundant food.

Although a number of studies have been done on the diel dynamics of heleoplankton in different parts of the world, such studies are unattended in this geographical region. Therefore the present investigation is aimed to record the diel fluctuation in the numerical densities of heleoplankton groups with respect to the physicochemical attributes of pond water in an aquaculture tank in Guwahati, Assam.

\section{MATERIALS AND METHODS}

The present investigation was carried out during the Monsoon season of 2004 in a freshwater fish pond situated in the Aquaculture site of UGC-SAP (DRS) Project, Department of Zoology, Gauhati University. The pond lies on latitude $20^{\circ} 09^{\prime} 26 \mathrm{~N}$ and longitude $91^{\circ} 40^{\prime} 21 \mathrm{E}$. The surface area of the pond is about 1.4 hac with mean depths during monsoon and retreated period are respectively $2.5 \mathrm{~m}$ and $1.2 \mathrm{~m}$.

The physico-chemical parameters of water selected in the present investigation in order to study their diel fluctuation are Water Temperature (WT), $\mathrm{pH}$, Dissolved Oxygen (DO), Free Carbon dioxide $\left(\mathrm{FCO}_{2}\right)$, Total Alkalinity (TA) and Total Hardness (TH). The samples of water and plankton were collected simultaneously for 24 hours (8 $\mathrm{AM}$ of the day to $8 \mathrm{AM}$ of the next day) at an interval of 4 hours.

The physico-chemical parameters were estimated from the collected water samples by following the methodology based on APHA (1988) and NEERI (1988). The quantitative $\left(\mathrm{n} . \mathrm{l}^{-1}\right)$ analysis of plankton was done by following the ISSN : 0974-9411 (Print), 2231-5209 (Online) All Rights Reserved ๑ Applied and Natural Science Foundation www.ansfoundation.org 
method of Welch (1948). The phytoplankton were recorded as unit cell per liter while the zooplankton as individual number per liter of the pond water. In case of filamentous and colonial phytoplankters, one filament or one colony was considered as one unit. Identification of the phytoplankton was done up to generic level with the help of standard keys, books and works (Edmondson, 1959; Smith, 1971) while the zooplankton was identified upto the species level by consulting various works (Pennak, 1953; Edmondson, 1959 and Tonapi, 1980).

\section{RESULTS AND DISCUSSION}

In the diel cycle of day and night, the surface water temperature of the studied pond showed a day time increase reaching the maximum at 4 PM which declined to the minimum at $4 \mathrm{AM}$ due to the action of overlying wind of night hours (Talling, 2004). Moreover, a positive relationship among water temperature, $\mathrm{pH}$ and $\mathrm{DO}$ (Table 4) has been discernable in the studied pond. Such a relationship was also reported by Cressa (1993). However, an inverse diurnal trend was exhibited by TA with respect to water temperature $(\mathrm{r}=-0.915, \mathrm{p}<0.01)$ and $\mathrm{pH}(\mathrm{r}=-$ $0.822, \mathrm{p}<0.05)$ in the present observation. Similarly, an inverse correlation was also observed in the case of $\mathrm{FCO}_{2}$ with respect to water temperature $(\mathrm{r}=-0.854, \mathrm{p}<0.05)$, $\mathrm{DO}(\mathrm{r}=-0.793, \mathrm{p}<0.05)$ and $\mathrm{pH}(\mathrm{r}=-0.939, \mathrm{p}<0.01)$.

In the present investigation the significant variation ( $t-$ test, $p<0.01)$ in the emergence of phytoplankters during the day hours with their nocturnal decrease in density was clearly instituted. On the other hand, the zooplankters exhibit a significant increase (t-test, $\mathrm{p}<0.01$ ) in their numerical density during the night hours. Similar trend of diel variation in phytoplankton and zooplankton was reportedly established in fresh water bodies of India (Gaur and Khan, 1995) as well as in different parts of the world (Lauridsen et al., 1999; Easton and Gophen, 2003; Reichwaldt et al., 2005; Nakajima et al., 2008).

Among different phytoplankton groups significant diel

Table 1. Diurnal variation of physico-chemical parameters of the Pond water.

\begin{tabular}{lcccccc}
\hline Time & $\begin{array}{c}\text { Total } \\
\text { alkalinity } \\
\left(\mathrm{mg.}^{-1}\right)\end{array}$ & $\begin{array}{c}\text { Total hardness } \\
\left(\mathrm{mg.}^{-1}\right)\end{array}$ & $\begin{array}{c}\text { Water } \\
\text { temperature }\left({ }^{\circ} \mathrm{C}\right)\end{array}$ & $\begin{array}{c}\mathrm{FCO}_{2} \\
\left(\mathrm{mg}^{-1}\right)\end{array}$ & $\begin{array}{c}\mathrm{DO} \\
\left(\mathrm{mg}^{-1} \mathrm{I}^{-1}\right)\end{array}$ & $\mathrm{pH}$ \\
\hline 8:00 AM & 112 & 114 & 30.2 & 4 & 6.5 & 8.5 \\
12:00 Noon & 102 & 106 & 31.8 & 2 & 7.1 & 9.4 \\
4:00 PM & 90 & 104 & 32.4 & 4 & 6.9 & 9 \\
8:00 PM & 108 & 112 & 30.1 & 4 & 7.4 & 8.3 \\
12:00 Midnight & 122 & 120 & 28.5 & 8 & 6.2 & 7.5 \\
4:00 AM & 118 & 110 & 27.4 & 8 & 5.6 & 7.1 \\
8:00 AM & 110 & 116 & 29.8 & 4 & 6.4 & 8.3 \\
S.E. & 3.9966 & 2.11248 & 0.656366 & 0.857143 & 0.228274 & 0.301583 \\
S.D. & 10.574 & 5.58911 & 1.73658 & 2.26779 & 0.603955 & 0.797914 \\
t- test (p) & $1.61 \times 10^{-7}$ & $3.06 \times 10^{-9}$ & $7.3 \times 10^{-9}$ & 0.001 & $1.14 \times 10^{-7}$ & $1.15 \times 10^{-7}$ \\
Skewness & -0.478674 & 0.00721378 & -0.0776094 & 0.443958 & -0.204386 & -0.156916 \\
\hline
\end{tabular}

Table 2. Diurnal variation of numerical densities $\left(u .1^{-1}\right)$ of phytoplankton groups and total phytoplankton

\begin{tabular}{lcccccc}
\hline Time & Myxophyceae & Chlorophyceae & Euglenineae & Dinophyceae & Bacilleriophyceae & $\begin{array}{c}\text { Total } \\
\text { phytoplankton }\end{array}$ \\
\hline 8:00 AM & 388 & 1265 & 80 & 18 & 24 & 1775 \\
12:00 Noon & 520 & 1543 & 120 & 25 & 45 & 2253 \\
4:00 PM & 958 & 1015 & 112 & 32 & 25 & 2142 \\
8:00 PM & 435 & 865 & 20 & 22 & 11 & 1353 \\
12:00 Mid-night & 210 & 688 & 8 & 19 & 2 & 925 \\
4:00 AM & 135 & 1150 & 25 & 21 & 5 & 1331 \\
8:00 AM & 365 & 1247 & 64 & 24 & 26 & 1726 \\
S.E. & 118.796 & 123.458 & 20.1898 & 2.08833 & 7.09342 & 210.907 \\
S.D. & 290.989 & 302.409 & 49.4547 & 5.11534 & 17.3753 & 516.615 \\
t- test (p) & 0.0138 & 0.0003 & 0.0296 & 0.0001 & 0.0567 & 0.0006 \\
Skewness & 0.659877 & 0.0225432 & 0.659877 & 0.0225432 & 0.659877 & 0.0225432 \\
\hline
\end{tabular}




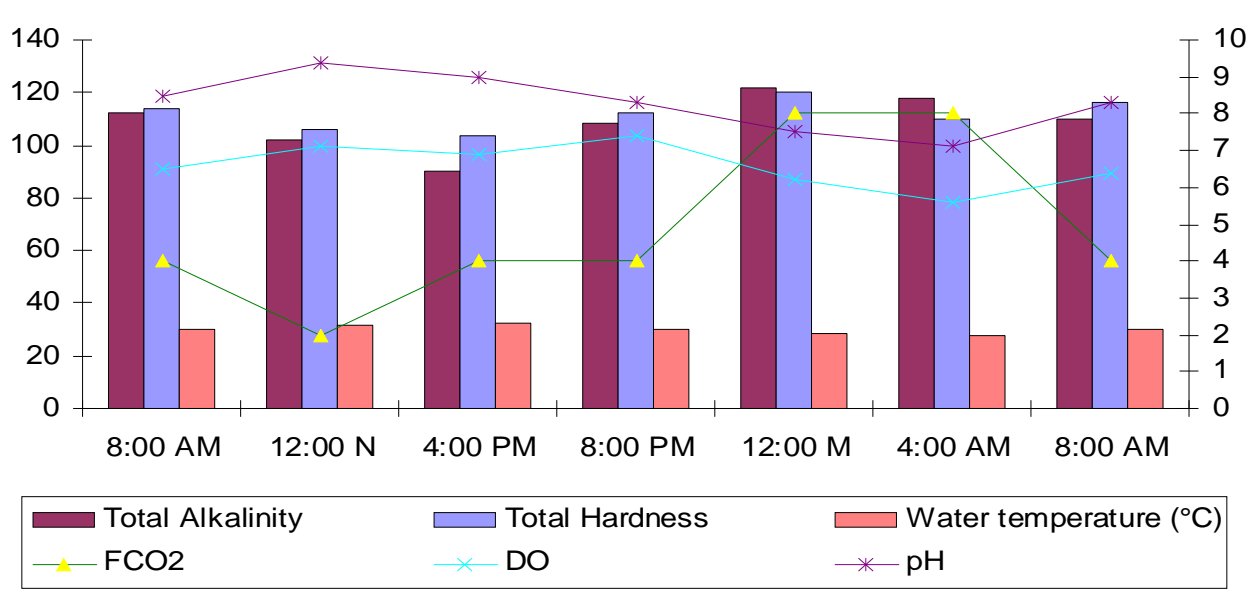

Fig. 1. Diurnal variation of physico-chemical parameters of water $\left(\mathrm{mg} . \mathrm{I}^{-1}\right)$ of the Pond.

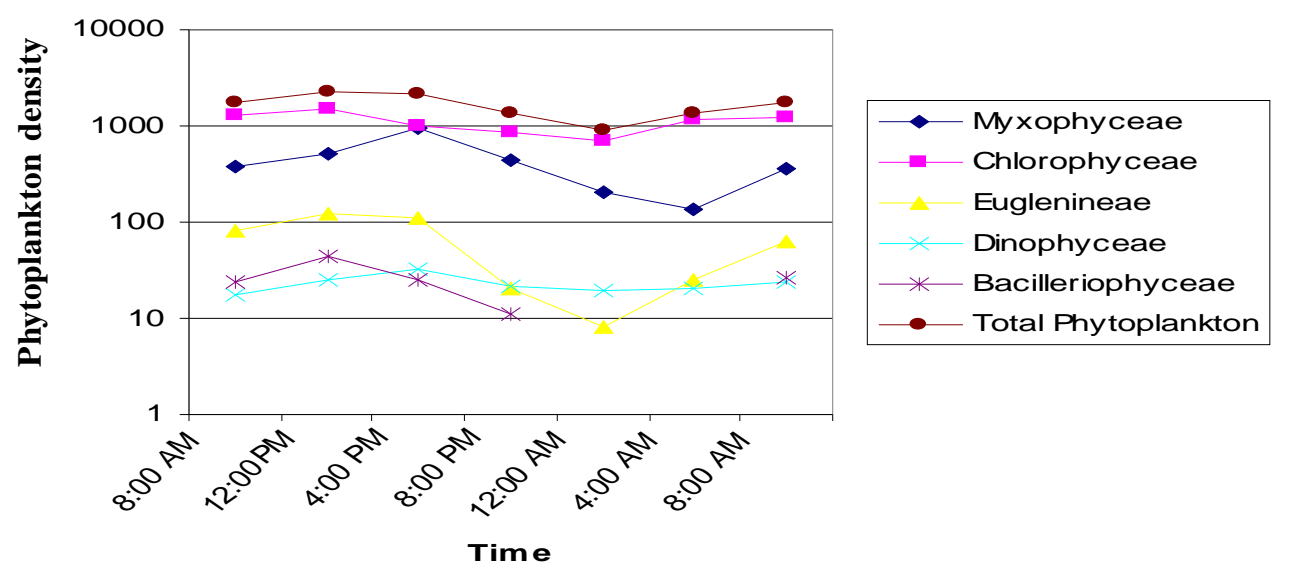

Fig. 2. Diurnal variation of numerical densities $\left(\mathrm{u}^{\left.\mathrm{I}^{-1}\right)}\right.$ of total phytoplankton and phytoplankton groups.

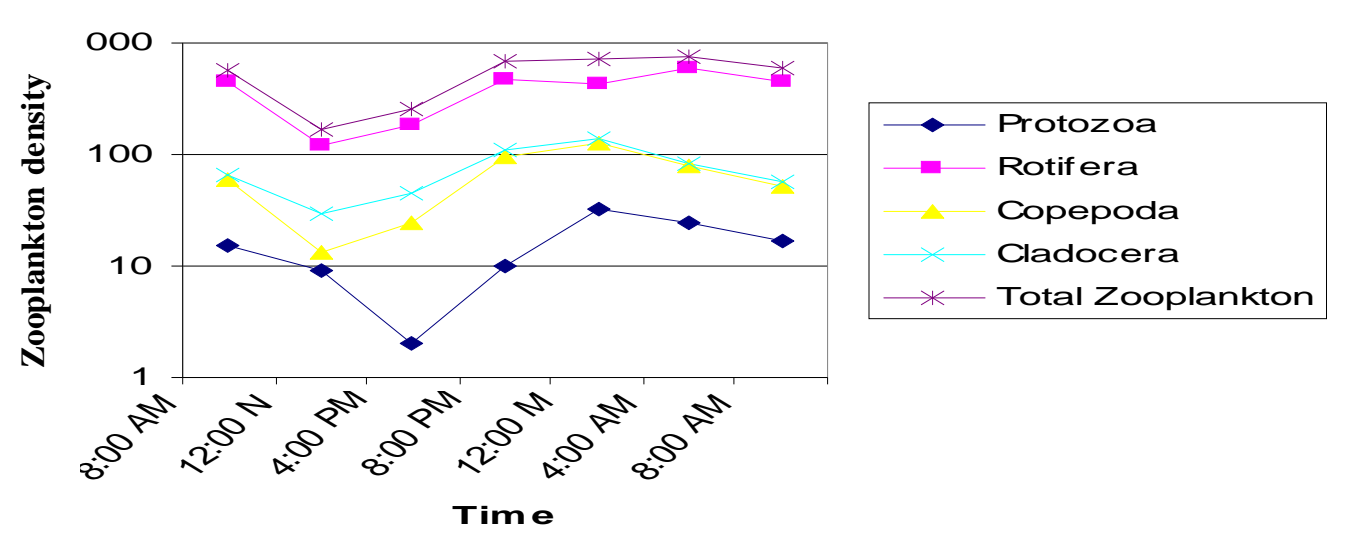

Fig. 3. Diurnal variation of numerical densities $\left(n . l^{-1}\right)$ of total zooplankton and zooplankton groups.

variation in numerical density (Table 2 ) is observed in Myxophyceae (t-test, $\mathrm{p}<0.05$ ), Chlorophyceae (t-test, $\mathrm{p}<0$ $.01)$, Euglenineae (t-test, $\mathrm{p}<0.05$ ) and Dinophyceae (t-test, $\mathrm{p}<0.01)$. However, the diel fluctuation in the group Bacilleriophyceae is found insignificant ( $t$-test, $p>0.05$ ). Besides, the significant diurnal variation (Table 3 ) in numerical density is also recorded in the zooplankton groups like Protozoa (t-test, $\mathrm{p}<0.05)$, Rotifera (t-test, $\mathrm{p}<0$ $.01)$ Copepoda (t-test, $\mathrm{p}<0.05)$ and Cladocera (t-test, $\mathrm{p}<0$ $.01)$.
In the present investigation altogether seventeen species of phytoplankters are found to exhibit more or less diurnal fluctuation in their population density, of which Microsystis sp., Trachelomonas sp., Lyngbya sp. and Staurastrum $\mathrm{sp}$. register their highest density at 8 am (Fig. 4). Higher density of Lyngbya hieronymusii and Staurastrum anatinum during the morning hours is also reported by Goswami (1985) while Verma (1967) recorded maximum density of Trachelomonas at $9 \mathrm{am}$. Morning abundance of Microsystis sp. with subsequent decrease 
Table 3. Diurnal variation of numerical densities (n.1 $\left.{ }^{-1}\right)$ of zooplankton groups and total zooplankton.

\begin{tabular}{lccccc}
\hline Time & Protozoa & Rotifera & Copepoda & Cladocera & Total Zooplankton \\
\hline 8:00 AM & 15 & 440 & 60 & 64 & 579 \\
12:00 N & 9 & 120 & 13 & 29 & 171 \\
4:00 PM & 2 & 185 & 25 & 45 & 257 \\
8:00 PM & 10 & 464 & 96 & 112 & 682 \\
12:00 M & 32 & 431 & 128 & 138 & 729 \\
4:00 AM & 24 & 585 & 78 & 81 & 768 \\
8:00 AM & 17 & 459 & 53 & 58 & 587 \\
S.E. & 4.46965 & 73.1216 & 17.7119 & 16.7838 & 104.108 \\
S.D. & 10.9484 & 179.11 & 43.3851 & 41.1116 & 255.011 \\
t-Test $(\mathrm{p})$ & .0186 & .0038 & .0131 & .0055 & .0037 \\
\hline
\end{tabular}

Table 4. Values of Carl Pearsons Coefficient of correlation (r) showing significant correlation among the physico-chemical parameters and numerical densities of phytoplankton and zooplankton.

\begin{tabular}{|c|c|c|}
\hline $\begin{array}{l}\text { Physico-chemical parameters, phytoplankton and } \\
\text { zooplankton }\end{array}$ & Coefficient of correlation $(r)$ & t-test $(p)$ \\
\hline $\mathrm{TA}$ and $\mathrm{TH}$ & +0.817 & 0.024 \\
\hline TA and WT & -0.915 & 0.004 \\
\hline TA and $\mathrm{pH}$ & -0.822 & 0.023 \\
\hline TA and phytoplankton density & -0.837 & 0.018 \\
\hline TA and zooplankton density & +0.842 & 0.017 \\
\hline WT and $\mathrm{FCO}_{2}$ & -0.854 & 0.015 \\
\hline WT and DO & +0.782 & 0.038 \\
\hline WT and $\mathrm{pH}$ & +0.965 & 0.0004 \\
\hline WT and phytoplankton density & +0.845 & 0.017 \\
\hline WT and zooplankton density & -0.906 & 0.005 \\
\hline WT and $\mathrm{FCO}_{2}$ & -0.939 & 0.002 \\
\hline $\mathrm{DO}$ and $\mathrm{pH}$ & +0.782 & 0.038 \\
\hline $\mathrm{DO}$ and $\mathrm{FCO}_{2}$ & -0.793 & 0.033 \\
\hline $\mathrm{FCO}_{2}$ and $\mathrm{pH}$ & -0.939 & 0.002 \\
\hline $\mathrm{FCO}_{2}$ and phytoplankton density & -0.830 & 0.021 \\
\hline $\mathrm{FCO}_{2}$ and zooplankton density & +0.758 & 0.048 \\
\hline $\mathrm{pH}$ and phytoplankton density & +0.881 & 0.009 \\
\hline $\mathrm{pH}$ and zooplankton density & -0.912 & 0.004 \\
\hline
\end{tabular}

during the day hours corroborates the findings of Takamura and Yasuno (1984). Contrary to this, some researchers recorded maximum density of Mycrosystis aeruginosa at 12 noon and 4 pm (Gaur and Khan, 1995). However, the density of many phytoplankters namely, Nostoc sp., Cosmarium sp., Closterium sp., Euglena sp., Ceratium sp., Peridinium sp., Navicula sp., F rustulia sp., Asterionella sp. and Cyclotella sp. in the present study have increased from the morning hours to reach the peak at around $4 \mathrm{pm}$ (Fig. 4). Moreover, three species namely Spirulina sp. and Volvox sp. exhibit their maximum abundance at 12 noon (Fig. 4). More or less similar trends are also reported by Goswami (1985). On the other hand, the present observation does not corroborate the findings of Verma (1967) who reported the maximum density of Euglena in surface water at noon hours and Blaauboer (1982) who accounted the maximum density of Ceratium hirudinella during the evening and night hours 

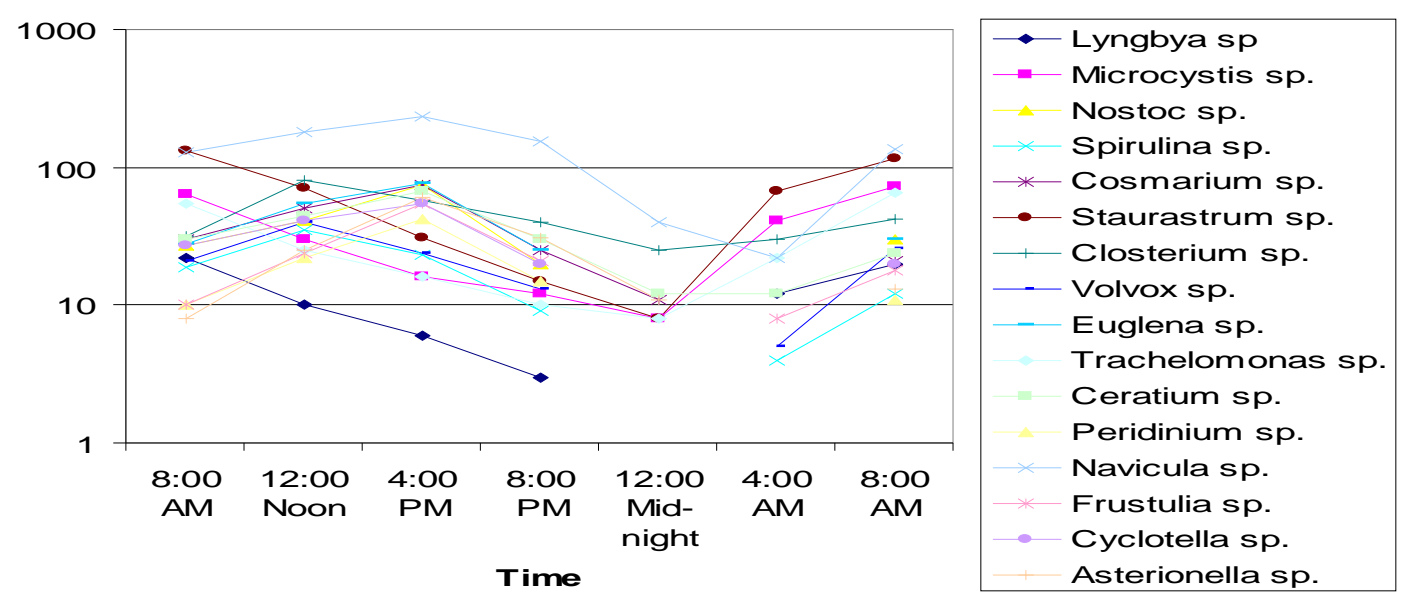

Fig. 4. Diurnal variation of numerical densities $\left(\right.$ u. $\left.^{-1}{ }^{-1}\right)$ of phytoplankton species.

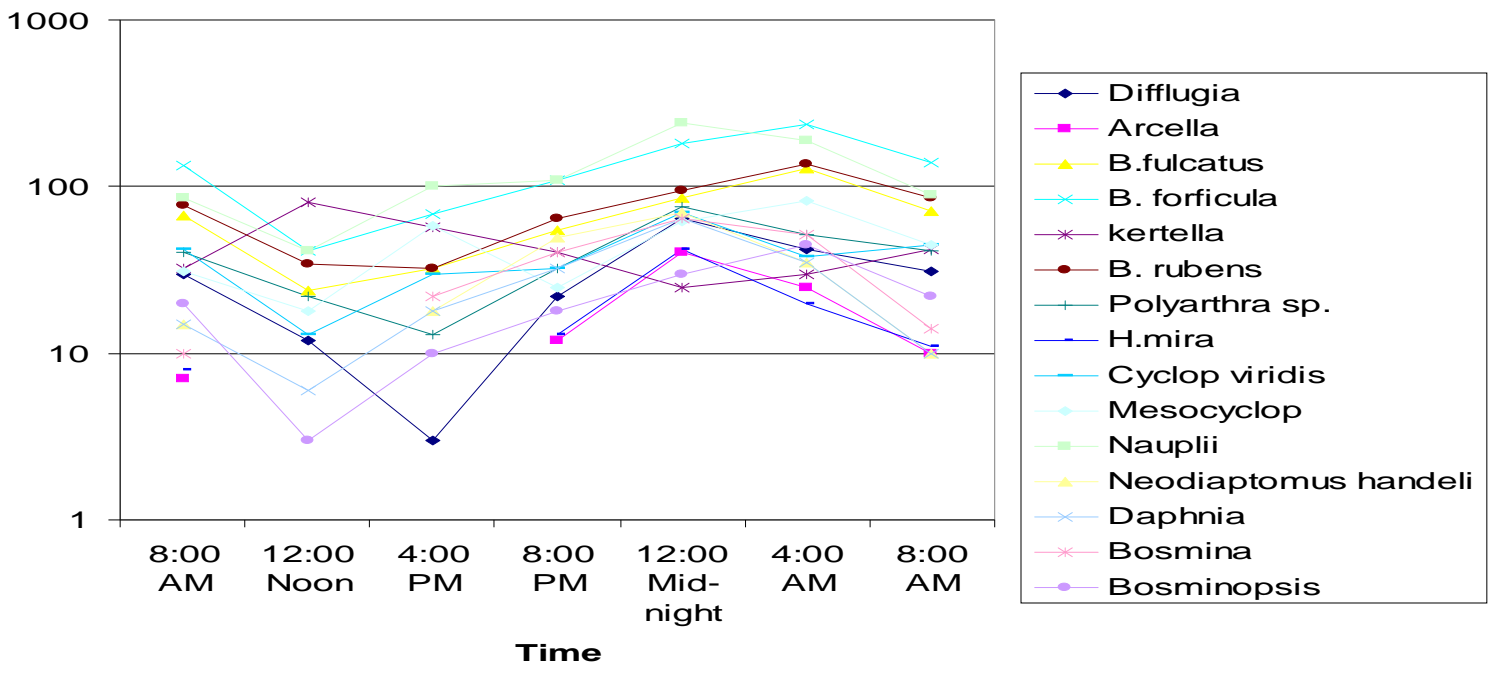

Fig.5. Diurnal variation of numerical densities $\left(n . I^{-1}\right)$ of zooplankton species.

with subsequent decrease in the morning hours.

In addition to this, the trend of diurnal fluctuation of zooplankton groups is different according to its major constituent members, the quantitative variation of which eventually determined the density of the whole zooplankton community. In general, the Brachionids except Keratella exhibit an increase in their density from the evening and attaining peak at around 4 am which gradually decrease during the day hours and maintain the trough period at the mid day hours (Fig. 5). Contrary to this, an increase in the density of Keratella is discernible in the studied pond during the day hours (Fig. 5) corroborating the findings of Zanatta et al. (2007). However, Kemdirim (2000) did not find diel movement in Keratella sp. and Hexarthra sp. in Kangimi reservoir, Nigeria. In the present study, Copepods and Cladocerans tend to produce their maximum density mostly during the mid night hours (Fig. 3). Chang and Hanazato (2004) also reported a two or three times increase of M esocyclop sp. density at the midnight hours over the day time density. Muluk and Beklioglu
(2005) reported a significant increase in the Daphnia population during the night hours.

The causative factors for diel movements of plankters are a complex phenomenon (Welch, 1952). Although light intensity is considered to be the principal factor (Kemdirim, 2000, Pinilla, 2006) having control over the vertical migration of limnoplankton, the actual causes of such migration still appear speculative. Reichwaldt et al. (2005) reported that the diel vertical migration of D aphnia spp. is effected by the fluctuation of water temperature. Moreover, in fish ponds, plankton are highly influenced by the predation pressure of planktivorus and omnivorus fishes (Sarvala et al., 1998; Tatrai et al., 2003; Pasternak et al., 2006). Easton and Gophen (2003) on the other hand opined that diel vertical migration do not substantially reduce the predation risk of zooplankton prey with the fish.

In present study, total population density of phytoplankton exhibited positive and significant correlations with water temperature $(r=0.845, \mathrm{p}<0.05)$ and 
$\mathrm{pH}(\mathrm{r}=0.881, \mathrm{p}<0.01)$ while it maintained significant negative correlations with $\mathrm{TA}(\mathrm{r}=-0.837, \mathrm{p}<0.05), \mathrm{TH}(\mathrm{r}=$ $-0.768, \mathrm{p}<0.05)$ and $\mathrm{FCO}_{2}(\mathrm{r}=-0.830, \mathrm{p}<0.05)$. In contrast, total numerical density of zooplankton revealed positive and significant correlations with TA $(r=0.842, \mathrm{p}<0.05)$ and $\mathrm{FCO}_{2}(\mathrm{r}=0.758, \mathrm{p}<0.05)$ while it showed significant negative correlations with water temperature $(r=-0.906$, $\mathrm{p}<0.01)$ and $\mathrm{pH}(\mathrm{r}=-0.912, \mathrm{p}<0.01)$.

In conclusion, the present investigation portraits different degrees of the diel fluctuation in the population densities of phytoplankton and zooplankton groups in an aquaculture tank in this subtropical region. Further, the physico chemical parameters such as water temperature, $\mathrm{DO}, \mathrm{FCO}_{2}$, TA show significant variation in the studied pond at different times of the day. Multivariate correlation analysis performed in the present study reveals an important information regarding the correlation of diel dynamics of heleoplankton with some physico-chemical attributes of pond water.

\section{ACKNOW LEDGEMENTS}

The authors are thankful to the Head, Department of Zoology, Gauhati University for providing the laboratory facilities of the department and the aquaculture laboratory of UGC-SAP (DRS) Project during the period of investigation.

\section{REFERENCES}

APHA (1989). Standard Methods for the examination of water and waste water. American Public Health Association $17^{\text {th }}$ Edition. Washington, D.C.1193 pp.

Blaauboer, M.C.I. (1982). The phytoplankton species composition and the seasonal periodicity in Lake Vechten from 1956 to 1979. Hydrobiologia, 95 : 25-36.

Chang, Kwang-Hyeon and Hanazato, T. (2004). Diel vertical migrations of invertebrate predators (Leptodora kindtaii, Thermocyclop taihokuensis and M esocyclop sp.) in shallow eutrophic lake. Hydrobiologia, 528 : 249- 259.

Cressa, Claudia (1993). Diel variations in some chemical variables of the Orituco River, Venezuela. E cotropicos, 6 (2) : 30-42

Easton, J. and M. Gophen, M. (2003). Diel variation in the vertical distribution of fish and plankton in Lake Kinneret: a 24-h study of ecological overlap $\mathrm{H}$ ydr obiologia 491: 91-100

Edmondson, W.T. (1959). Fresh Water Biology, $2^{\text {nd }}$ ed. International Books and Periodical Supply Service, New Delhi, pp.xx + 1248 pp.

Gaur, Rajeev K. and Khan, Asif Ali (1995). Diurnal profile of some physico-chemical and biological parameters in a freshwater lentic ecosystem with a permanent bloom of a Cyanobacterium, Micrcystis aeroginosa (Kuetz.). J. Freshwater Biol., 7 (3) : 169-175.

Goswami, M.M. (1985). Limnological Investigations of a tectonic lake of Assam, India and their bearing on fish production. Unpublished Ph.D. Thesis, Gauhati University, Assam. pp. 395

Hanazato, T. and Yasuno, M. (1989) Zooplankton community structure driven by vertebrate and invertebrate predators.
Oecologia, $81: 450-458$

Haney, J.F. (1993) Environmental control of diel vertical migration behaviour. Arch $\mathrm{H}$ ydrobiol Beih E rgeb Limnol 39 $: 1-17$

Horpilla, J., Malinen, T., Nurminen, L., Tallberg, P. and Vinni, M. (2000) A metalimnetic oxygen minimum indirectly contributing to the low biomass of cladocerans in Lake Hiidenvesi - a diurnal study on the refuge effect. Hydrobiologia, 436:81-90.

Kemdirim, E.C. (2000). Diel rhythm of plankton and physicochemical parameters inKangimi Reservoir, Kaduna State Nigeria. J . Aquatic Science, 15 : 35-39

Lampert, W. (1993). Ultimate causes of diel vertical migration of zooplankton: New evidence for the predator-avoidance hypothesis. Arch. Hydrobiol. Beih., 39 : 79-88.

Lauridsen T.L., Jeppesen, E., Mitchell, S.F., Lodge, D.M. and Burks, R.L. (1999). Diel variation in horizontal distribution of Daphnia and Ceriodaphnia in oligotrophic and mesotrophic lakes with contrasting fish densities H ydr obiologia, 408/409: 241-250.

Leibold M.A. (1990). Resources and predation can affect the vertical distribution of zooplankton. Limnol 0 ceanogr 35:938-944

Melo Sergio de and Huszer Vera Lucia M. (2000). Phytoplankton in an Amazonian flood-plain lake (Lago Batata, Brasil): diel variation and species strategies. J ournal of Plankton Research, 22 (1):63-76

Muluk, C.B. and Beklioglu, M. (2005). Absence of typical diel vertical migration in Daphnia : varying role of water clarity, food and dissolved oxygen in Lake Eymir, Turkey. Hydr obiologia, 537 : 125-133.

Nakajima, R., Yoshida, T. Othman, B.H.R. and Toda, T. (2008). Diel variation of zooplankton in the tropical coral-reef water of Tioman Island, Malaysia. Aquat. Ecol., DOI 10.1007/ s10452-008-9208-5

NEERI (1989). Manuals on water and waste water analysis: pp.320.

Pasternak, A.F., Mikheev, V.N. and Wanzenbock, J. (2006). How plankton Copepods avoid Fish predation: from individual responses to variations of the life cycle. J ournal of I chthyology, (46) : S220-S226.

Pennak, R.W. (1953). Freshwater invertebrates of the United States. Ronald Press Co. New York. pp.769.

Pinilla, Gabriel A. (2006). Vertical distribution of phytoplankton in a clear water lake of Colombian Amazon (Lake Boa, Middle Caqueta). H ydrobiologia, 568: 79-90

Reichwaldt E.S., Wolf I.D. and Stibor, H. (2005). Effects of a fluctuating temperature regime experienced by Daphnia during diel vertical migration on Daphnia life history parameters. Hydrobiologia, 543: 199-205

Ringelberg J. and Van Gool E. (2003). On the combined analysis of proximate and ultimate aspects in diel vertical migration (DVM) research. Hydrobiologia, $491: 85-90$

Sarvala, J., Helminen, H., Saarikari, V., Salonen, S. and Vuorio K. (1998). Relations between planktivorous fish abundance, zooplankton and phytoplankton in three lakes of differing productivity. H ydrobiologia, 363 : 81-95.

Smith, G.M. (1971). Cryptogamic Botany. Algae and Fungi. Vol. I. T.M.H. edn. 546 pp. M C. Graw H ill Book Co. Inc. New York. 
Talling, J.F.(2004). Interrelation of diel and seasonal change, involving summer stratification, weather variables and a mobile dinoflagellate in a productive English lake. H ydrobiologia, 524: 215-227

Tatrai, I., Matyas, K., Korponai, J., Paulovits, G., Pomogyi, P. and Heri, J. (2003). Regulation of plankton by omnivore cyprinids in a shallow lake in the Kis-Balaton reservoir system. Hydrobiologia, $504: 241-250$.

Takamura, N. and Yasuno, M. (1984). Diurnal changes in the vertical distribution of phytoplankton in hypertrophic Lake Kasumigaura, Japan. Hydrobiologia, 112 (1) : 53-60.

Tonapi, G.T. (1980). Fresh water animals of India, an ecological approach, Oxford and IBH Publishing Co. Pvt. Ltd. New
Delhi.

Verma, N. (1967). Diurnal variation in a fish pond in Seoni, India. H ydrobiologia, 30 (I): 129-36.

Welch, P.S. (1948). Limnological Methods, Blakiston, Philadelphia, pp.381.

Welch, P.S. (1952). Limnology. Mc Graw Hill Book Co. New York and London, pp.471

Zanatta, Sandra A., Orzco, B.R., Torres, Hurtado J.A.Z and Hernandez, A.P. (2007). Plankton rotifers from a tropical lake: Differences in distribution and migration patterns in two mixing events, with similar abiotic conditions. Hidrobiologica, 17 (1) : 1-10. 